\title{
Perceptions on Shariah Governance Framework of Islamic Banking in Oman: Issues and Challenges
}

\author{
Abdulrahman Alnofli(1), Engku Rabiah Adawiah Engku Ali(2)
}

\begin{abstract}
Oman has adopted Shari'ah governance framework which is very similar to other countries that face issues of Shari'ah governance such as independence, competency and disclosure. Therefore, this study will examine these main issues in the Shari' ah governance framework of Oman. This paper aims to examine the current practice of Shar' ah governance in Oman from the perspectives of Sharì'ah advisors, bankers and regulators. The paper focuses on the present practice of Shari' ah governance framework and related issues such as independence, competency and disclosure. The paper uses the descriptive research method in terms of collecting secondary data and information for the literature review. Since the availability of data and information on Shari' ah governance practices in Oman is very limited, a semi-structured interview was conducted with Sharì'ah advisors, officers and regulators to explore their perceptions on Sharī'ah governance and related issues. The findings of the paper reveal that the regulators have put in place an excellent Shari'ah governance framework and it may be considered as one of the best frameworks in the Islamic banking industry. However, there are shortcomings and weaknesses in the current practice of Shari'ah governance framework, such as lack of experience, lack of research in the field of Islamic banking and finance and low position of internal Sharì ah review. This study provides and proposes some recommendations for enhancing the present Sharì'ah governance framework.
\end{abstract}

Keywords: Shariah, Governance, Oman, Framework, Islamic Banking.

\section{تصورات حول إطار الحوكمة الشرعية للصيرفة الإسلامية في عمان: قضايا وتحديات

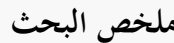

تتبنى عمان نظاما للحوكمة الشرعية شبيها لنظام الحوكمة في بعض الدول التي تواجه بعض المشكلات التي تتمثل في الاستقلالية والشفافية والكفاءة مما يجعل احتمال أن تتكرر هذه المشكلات في عمان. هدفت الدراسة إلى بحث وتقصي إطار الحوكمة الشرعية الحالي في عمان من منظور المنظمين وأعضاء

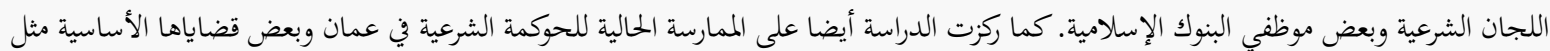
الاستقلالية والكفاءة والشفافية. استخدمت الدراسة أسلوب البحث الوصفي من حيث جمع البيانات والمعلومات الثانوية في الدراسات السابقة، ونظرا لقلة الدراسات في هذا الموضوع تم استخدام أسلوب المقابلة شبه المنظمة مع أعضاء اللجان الشرعية والمنظمين وبعض موظفي البنوك لدراسة نظرقم حول نظام الحوكمة الشرعية في عمان. نتيجة الدراسة أظهرت أن إطار الحوكمة الشرعية للبنوك الإسلامية في عمان يمكن أن يكون واحدا من أفضل الأطر والأنظمة في صناعة المالية الإسلامية الحالية، إلا أن هناك بعض نقاط الضعف والنقص بحاجة إلى المعالجة مثل نقص الحبرة ونقص الدراسات في مجال البنوك الإسلامية والمالية في عمان وضعف مكانة المراجع الشرعي، وفي النهاية أوصت الدراسة القائمين والممارسين لنظام الحوكة الشرعية في عمان الأخذ بنتيجة وتوصيات الدراسة لتحسين نظام الحوكمة الحالي. كلمات مفتاحية: الشريعة، الحوكمة، عمان، إطار، البنوك الإسلامية.

(1) Phd Student, Institute of Islamic Banking \& Finance (IIiBF), International Islamic University Malaysia. abdoo-61@hotmail.com

(2) Prof., Institute of Islamic Banking \& Finance (IIiBF), International Islamic University Malaysia. rabiah@iium.edu.my

\section{Contents}

1. Introduction

2. Literature Review

2.1. Shariah Governance from Fiqh Perspective

2.2 Main Issues of Shariah Governance

2.2.1 Independence

2.2.2 Competency

2.2.3 Disclosure and Transparency

3. Problem Statement

4. Research Methodology

5. Analysis of Interview Questions
5.1 Analysis of the practice of Sharīah governance framework $Q(1-4)$

5.2 Analysis of the Features and Strengths of Shari'ah Governance Framework $Q(5-8)$

5.3 Analysis of the Problems and Weaknesses of Sharì'ah Governance Framework Q (9-11)

5.4 Analysis of Main Issues of Sharīah Governance Framework (12-22)

5.5 Analysis of Recommendations and Suggestions $Q(23$ 24)

6. Conclusion

References

Appendix
119 


\section{Introduction}

Islamic banking in the Sultanate of Oman is new compared to other Gulf countries. Banking and finance operations in the Sultanate were limited to commercial banking because the legislative regulations and laws did not allow Islamic banks to operate in the Sultanate until late 2012 when the Sultan made significant amendments to the Banking Law promulgated by Royal Decree 114/2000 (Ginena \& Hamid, 2015).

The Omani Central Bank introduced a new Sharī'ah governance framework for Islamic banking in the Sultanate to bring the country's Islamic finance industry forward. The Central Bank of Oman (CBO) launched the Sharī'ah governance framework in 2012 and required all Islamic banking institutions to fully comply with the Sharī'ah governance framework in 2013 (Ginena \& Hamid, 2015). The primary target is to provide a sound regulatory framework for the Islamic banks to operate within the required Sharī'ah framework. This will enhance and strengthen investors' confidence in the rapidly growing Islamic finance industry in Oman.

Islamic financial services are provided by two types of institutions under the purview of Islamic Banking Regulatory Framework (IBRF) (CBO, 2012). The first kind of these institutions is full-fledged Islamic banks that operate Islamic banking business, such as Nizwa Bank and Alizz Bank. These Islamic banks are regulated under the IBRF 2012. In addition, these institutions obtain the required license for their operations under the ambit of this Act.

Conventional banks offering Islamic banking services are the second type of institutions offering Islamic financial services in Oman. In Oman, there are six Islamic windows that apply both conventional and Islamic banking businesses. The literature shows that there are some crucial issues in Sharī'ah governance that should be solved to have an effective Sharī'ah governance implementation. The issues include matters such as independence, competency and disclosure.

\section{Literature Review}

\subsection{Shariah Governance from Fiqh Perspective}

In Islamic jurisprudence, we cannot find an exact terminology on governance in the classical texts.
However, we can attribute governance to the practice of Hisbah which has a close meaning to the term governance.

Hisbah means to seek reward etymologically. "A person who performs this role and seeks the reward of the divine for such work, is called muhtasib" (Ibn Manzūr, 1999). Terminologically speaking, AlMawardī (1989) defines hisbah as "commanding good if it [such good] is explicitly forsaken [in society] and prohibiting evil if it [such evil] is performed" (AlMawardī, 1989). This definition is mainly derived from the verse: "And let there be [arising] from you a nation inviting to [all that is] good, enjoining what is right and forbidding what is wrong, and those will be the successful” (3:104) (Ginena \& Hamid, 2015).

The definition of hisbah indicates that there is a broad area of application for hisbah which includes many aspects of life. Muhtasib means a person who plays a vital role in protecting the people's affairs from falling into forbidden elements, which is the primary objective of hisbah. In the context of the financial and economic sector, Ginena and Hamid (2015) lay out that hisbah institutions are a group which is qualified in Sharī'ah and responsible to prevent corruption and monitor the market to guarantee that all businesses and activities are fair. This group has a duty to maintain fairness, transparency and accountability while taking into consideration the Sharī'ah dimension.

To sum up, the function of muhtasib in the context of Sharī'ah governance is to supervise and ensure that all activities and transactions of the institution are Sharı̄’ah compliant.

\subsection{Main Issues of Shariah Governance}

The literature shows that there are some crucial issues in Sharī' ah governance that should be solved to have an effective Sharī'ah governance implementation. The issues include matters such as independence, competency and disclosure.

\subsubsection{Independence}

Accounting and Auditing Organization for Islamic Financial Institution (AAOIFI) Governance Standards (GS) No.5 para.2 (2015) defines independence as "An attitude of mind which does not allow the viewpoints 
and conclusions of its possessor to become reliant on or subordinate to the influences and pressures of conflicting interests. It is achieved through organizational status and in an objective way".

The issue of independence arises from the fact that Sharī'ah supervisory board members receive remuneration from the IFIs, which may lead to a potential conflict of interest (ISRA, 2016; Farook \& Farooq 2011; Garas \& Pierce, 2010). The problem comes from the perception that the members of the Sharī'ah supervisory board may legitimize illegal or dubious operations to keep their positions active as a member of the Sharī'ah Supervisory Board (SSB) in the Islamic financial institution (Rammal, 2006; Abdul Aziz, 2012; Lahsasna \& Saba, 2014). Another issue of independence of Sharī'ah board is the appointment of the SSB members which is made during Annual General Meeting (AGM); the board of director (BOD) may influence the shareholders in nominating the members of the SSB (ISRA, 2016). According to Rammal (2006), the members of the SSB should not be employees in the bank and must not be affected by the command of the BOD. The AAOIFI GS No.1 laid out that members of the SSB must be appointed by the shareholders during the AGM of the bank upon recommendation of the $\mathrm{BOD}$.

There is still a need for an effective Sharī'ah governance framework in the form of law or regulation to reinforce the credibility of the IFIs that rely heavily on the perceived independence of the SSB.

\subsubsection{Competency}

One of the main issues faced by the Islamic finance industry is the need for scholars who have an experience in Islamic finance. Recently, many IFIs sought out senior and well-versed Sharī'ah scholars to be members of their SSB. This is to enhance the confidence of clients who deal with the IFIs that wellversed Sharīah scholars of repute are observing the Sharī'ah compliance process (Belder et al., 2008; Abdul Aziz, 2012; Wilson, 2009; Gruening \& Iqbal, 2008; Hamza, 2013).The issue of competency may influence the efficiency of the SSB, particularly in issuing appropriate Sharī'ah rulings as they should possess the required professional education and training with expertise in Sharī'ah (ISRA, 2016). A survey has been conducted on the qualification of members of the SSB, and the survey has found that $76.6 \%$ of the SSB members have training and qualifications, while $8.6 \%$ were erudite in commercial and Sharì'ah law. However, only $11.4 \%$ have expertise in Sharī'ah, economics and law (Bakar, 2002). These practices may influence the competence of the Sharī'ah supervisory board's roles, especially since the SSB members are meant to provide robust and concrete Sharīah decision; they should possess sufficient knowledge and training with experience in Sharīah (ISRA, 2016).

\subsubsection{Disclosure and Transparency}

The current practice of Sharì'ah governance shows that the level of disclosure of necessary information is weak, even the information about Sharī'ah rulings are very hard to be viewed by the public (ISRA, 2016).

A survey has shown that there are shortcomings and weaknesses of disclosure of information practice, especially in the Sharī'ah report (Grais \& Pellegrini, 2006). Significant issues of Sharī'ah governance such as disclosure may affect the credibility and image of Islamic banks in the eye of the public and shareholders. Hasan (2011) conducted a survey on disclosure of Sharīah governance practice in GCC, UK, and Malaysia. He found that there are significant differences in the extent of disclosure practice. For example, in GCC countries the extent of disclosure practice was very low, where $55 \%$ of the IFIs were ranked in the (Emerging Practice) group and not one of them in the (Good Practice) or (Best Practice) groups. In the UK the level of disclosure practice was fair and better than GCC countries, where $20 \%$ of the IFIs were ranked in the (Improved practice) and (Good practice) groups.

It is interesting to note that the level of disclosure practice in Malaysia was slightly higher than the UK and GCC countries as more than $80 \%$ of IFIs were in the groups of (Improved Practice) and (Best Practice).

The literature describes the main issues and challenges of Sharì'ah governance framework and how these issues affect efficiency of Sharī'ah governance framework worldwide. In this regard, Oman has 
adopted a Sharì'ah governance framework very similar to other countries that faced these issues of Shari'ah governance. Therefore, this study will examine these main issues in the Sharī'ah governance framework of Oman.

\section{Problem Statement}

The literature argues that there are some significant issues and challenges pertaining to the current practice of Sharī'ah governance across the world, namely, with regards to independence, competency, and disclosure. These unresolved issues need to be examined properly. The literature shows that without solving these important issues of Sharī'ah governance, the system of Sharī'ah governance would not be efficient.

Oman adopted a Sharī'ah governance framework that is very similar with other countries such as Malaysia, Pakistan, and Bahrain. Therefore, there is a very high potential that the same issues of Shari'ah governance framework apply to Oman too. This similarity can be seen in the Sharīah governance framework issued by the Central Bank of Oman in 2012. Oman started to operate the Islamic banks in the last few years due to the increasing demand from the people. Prior to that there was no political will to have Islamic banks in Oman.

According to Mihajat (2018), there is a lack of independence of Sharī'ah governance of Islamic banks in Oman, especially with the relationship between management and SSB in Islamic banks and intents to disqualify members of SSBs. Moreover, some SSBs members who have less experience in the field of Islamic finance are facing some difficulties in understanding the nature of the business. Additionally, the shortage of independence is not only with SSB but also with other Sharì'ah organs like head of Shariah and its units.

Apparently, as far as the researcher is concerned, very few literature or data is available on the Sharī'ah governance framework and issues in Oman. Hence this study attempts to examine the Shari'ah governance framework of Oman to verify the real issues faced. Once the issues are identified and verified, this study will provide some recommendations that may assist in dealing with these issues.

\section{Research Methodology}

The interview method has been used in many different social studies, and it is considered one of the primary methods in data collection strategies (Blee \& Taylor, 2002).

This research adopts a qualitative method to answer the questions of the study. This research is categorized as a social research. Therefore, the qualitative research method could be a proper approach to address this kind of issues and to assure the originality and quality of the study as well. It is interesting to note that the researchers have conducted this study based on primary data gathered through an interview to obtain the opinion of the participants. The researchers adopt systematic procedures of coding and categorizing the data (Blee and Taylor, 2002). This process was carried out systematically in a particular method on the computer. The study conducted semistructured interviews with the members of the Shari' $a h$ supervisory board (SSB), members of the Higher Sharī'ah Supervisory Authority (HSSA) in the CBO and the internal Sharī'ah reviewers in different Islamic banks. The researcher, in semi-structured interviews, can vary the sequence of the questions and ask to add any questions whenever necessary (Bryman, 2001).

This paper has conducted personal interviews with 25 persons rather than group interview. The respondents are grouped into three categories, namely: HSSA members, SSB members and internal Shariah reviewers. Most of the interviewees are the SSB members because of their experience which is very significant and relevant to the study. Internal Shariah reviewers are included in the sample of interviewees because they deal directly with the SSB members. In order to get the perspective of the regulators on the topic researched, a group of the HSSA has been included in the sample for the study.

The interview was carried out in Oman and Malaysia from 10 July 2017 till 25 June 2018. Most of the interviews were conducted face-to-face using an audio thumb recorder which took around 25 to 40 minutes for each interview. On the other hand, some interviewees preferred to answer the questions by writing, so the researcher sent to them the interview question via email. 
Table 1 Details of the Respondents

\begin{tabular}{|c|c|c|c|c|}
\hline & HSSA & SSB & $\begin{array}{l}\text { Internal } \\
\text { reviewer }\end{array}$ & Sharīah \\
\hline Central Bank & 2 & & & \\
\hline Bank Nizwa & & 1 & 1 & \\
\hline Bank Alizz & & 2 & 1 & \\
\hline Bank Meethaq & & 3 & 1 & \\
\hline Sohar Islamic & & 1 & 1 & \\
\hline Bank Al-Yusr & & 3 & 1 & \\
\hline $\begin{array}{l}\text { Al-Hilal } \\
\text { Islamic }\end{array}$ & & 1 & 1 & \\
\hline Bank Maisara & & 2 & 1 & \\
\hline Bank Al-Muzn & & 2 & 1 & \\
\hline
\end{tabular}

In order to meet the objectives of study, the researchers have examined and analyzed the interview transcripts. The primary aim of the research is to evaluate and analyze the Shariah governance framework of Oman. The table below shows the link between interview questions and the objectives of the study as an introduction for the interview findings, which are presented in the following sections.

Table 2: The Linkage between the Questions and Research Objectives

\begin{tabular}{|c|c|}
\hline Questions Linked to Objectives & Questions \\
\hline $\begin{array}{l}\text { 1. To investigate the practice of Shari'ah } \\
\text { governance framework of Islamic banking in } \\
\text { Oman }\end{array}$ & Q1-Q4 \\
\hline $\begin{array}{l}\text { 2. To examine the real features and } \\
\text { strengths of the Shari'ah governance } \\
\text { framework for Islamic banking in Oman. }\end{array}$ & Q5-Q8 \\
\hline $\begin{array}{l}\text { 3. To identify problems and weaknesses } \\
\text { faced by SSB and internal Sharī'ah reviewers } \\
\text { under Sharī'ah governance framework of } \\
\text { Oman. }\end{array}$ & Q9-Q11 \\
\hline $\begin{array}{l}\text { 4. To verify the extent of independence, } \\
\text { competency and disclosure practiced by } \\
\text { Sharì'ah board members in Omani Islamic } \\
\text { banks. }\end{array}$ & Q12-Q22 \\
\hline
\end{tabular}

\section{Analysis of Interview Questions}

\subsection{Analysis of the practice of Sharīah governance framework Q (1-4)}

This section demonstrates the analysis of the respondents' responses on the practice of Shari'ah governance framework in Oman. It is interesting to note that all the interviewees are unanimous that
Shari' 'ah governance framework of Oman is one of the best frameworks in the Islamic banking industry. The regulators got experience and benefits from various countries such as Malaysia, Pakistan and the Middle East. Due to the late issuance of their framework, Oman has the chance to learn from the mistakes of other countries. Some respondents assert that the Sharīah governance framework of Oman without any doubt needs more improvement. It is interesting to mention that one member of the HSSA said that AAOIFI has declared that the Sharī'ah governance framework of Oman is a good model in the aspect of Sharìah governance and work ethics for all Islamic banks worldwide. A question was asked to the Grand Mufti of Oman about his opinion on Sharī'ah governance and he answered "I encourage having Sharì'ah governance in the Islamic banks provided that they are committed to Sharī'ah principles. Moreover, I encourage having Shari'ah governance in all transactions by the people with the condition of Sharì'ah compliance."

In terms of Sharīah processes to assure Sharì'ah compliance in the Islamic bank, most of the respondents have mentioned that the Islamic banks in Oman have the SSB and Sharī'ah department. Sharī'ah department has two units which are Sharīah compliance unit and Sharīah audit. Sharīah compliance unit is concerned with ensuring compliance with Sharīah before launching the product, while Sharī'ah audit unit inspects and audits transactions after their execution. Some of the interviewees have added that all Islamic banks in Oman have an external Shari'ah audit which gives more confidence in the Islamic banks in the hearts of the public in terms of Sharī'ah compliance. Moreover, the IBRF set rules in case the Islamic bank does not follow the decisions issued by the SSB.

Regarding the Sharī'ah board, majority of the respondents, $88 \%$, have explained that the SSB roles include issuing fatwa, reviewing contracts and policies, issuing Sharī'ah reports, and serving in advisory capacity to the banks. Only one SSB member has added that the role of SSB should include more roles such as educating and training the staff of the banks, training the members of the BOD, and creating awareness among the public and answering their questions regarding Islamic banks. Moreover, one member of the 
SSB has mentioned that the SSB members should follow up the transactions after the implementation in all branches of the bank by visiting them through Sharī'ah auditors.

In terms of having centralized SSB in the CBO, $80 \%$ of the interviewees have stated that the HSSA gives a great support and benefit to the Islamic bank and finance industry in terms of supervision, organization and harmony with the Sharī'ah scholars' views. Moreover, they have not found any interference between the HSSA and the SSB because all of them know their responsibilities and duties to each other. Some Sharīah scholars have highlighted that the centralized HSSA is helpful in controlling and limiting the executions given to the bank by some of the SSB. They add that Oman has different madhahib (Islamic schools of law), such as 'ibadi, sunni and shi' $i$. Therefore, having a centralized HSSA in the CBO will help to harmonize and centralize the points of view faster and smarter. Also, it will give more confidence to the public. However, some respondents, $12 \%$, have admitted that the centralized HSSA is only a repeat of the SSB and having a centralized HSSA in the CBO will restrict and limit the work of the SSBs. This centralized HSSA will slow the process in issuing a new product. Moreover, having a centralized HSSA can kill the creativity of the SSB by placing more restrictions (they have said: why do we need a repeat of the SSB?). A member of the HSSA has added that full independence is given to the SSBs in expressing their views and opinions. And he has added that we only require some clarifications and modifications on their opinions, and that, sometimes, the SSB convinced the HSSA about their opinion. So, we do not intervene with the work of the SSB.

This finding indicates that, first, Oman has one of the best Sharīah governance frameworks in the industry. One reason for this is the lateness to launch Islamic banking by Oman, enabling it to get experience from many countries that have been in the system earlier. However, this framework without any doubt needs more improvement. Second, Sharī'ah Scholars understand their functions very well. However, most of them are concerned with the roles of supervision, advice and issuing fatwa, while the SSB members, as the key players in Sharī'ah governance, are required to give more attention to increase the awareness and culture of Islamic banking among all staff and the public. This is very important because the information available to many people in Oman about Islamic banking is still little. In terms of having a centralized HSSA in the CBO, the finding is that the existence of the HSSA in the CBO is healthy for the industry to supervise and harmonize the various views of Shari'ah scholars. According to some SSB members, the HSSA as a regulatory body should give Sharī'ah scholars more room for independence. Moreover, the HSSA needs to be faster in their decisions such as approval of new products.

\subsection{Analysis of the Features and Strengths of Sharī'ah Governance Framework Q (5-8)}

This section identifies four questions pertaining to features and strengths of Sharīah governance framework of Oman. The first question attempts to demonstrate the most significant features of Omani Sharī'ah governance framework. The second question explores the state of communication between SSB and other organs of governance. The third question shows the satisfaction of the SSB with the Shari'ah department in the bank. The fourth question examines the strength of the internal policy of the bank to ensure effective implementation of Sharī'ah governance.

With regard to features and strengths of Sharī'ah governance framework of Oman, most of the interviewees, $88 \%$, have mentioned that Sharīah governance framework of Oman has some unique features which are not found in other Sharìah governance frameworks, such as having a centralized HSSA, segregation of responsibilities of all the key functions, clear determination of the responsibilities, easy communication between the HSSA and the SSB, having external Sharī'ah audit, keeping up with the changing financial services industry, and publishing a paper annually by the internal Sharī'ah reviewer. Moreover, some respondents, $12 \%$, have explained that one of the main features of the Shari'ah governance framework of Oman is close monitoring of the Islamic banks by the CBO itself to ensure Shari' ah compliance in all transactions. The CBO performs this mission by sending their staff to the management of the Islamic banks regularly in order to ensure Sharī'ah compliance. 
The CBO was asked the same question and it replied "One of the unique features of the Islamic banking Regulatory Framework issued by the Central Bank of Oman is creating a true Sharīah compliance perception of Islamic banking and providing a structure and system to govern all the business activities of the Islamic banking institutions in Oman in order to ensure Sharī'ah compliance at all times and at all levels. Moreover, this system will enable Islamic banks to be perceived as Sharīah compliant by the stakeholders, including the general public. And this could be the hallmark of Sharī'ah governance framework mandated in the regulatory framework."

In terms of communication between the SSB and other organs of governance, most of the respondents, $88 \%$, have admitted that the SSBs have great communication with other organs such as the BOD, management, external Sharī'ah department and Shari' 'ah department. For example, one of the SSBs has mentioned that they have meetings with the BOD two times a year and regular meetings with the management, as well as the external Sharī'ah auditor. However, some interviewees, $12 \%$, have indicated that the communication between the SSB and other organs of governance is very weak. They have explained that they have good communication only with the Shari'ah department, while they only have one meeting with the BOD which is not sufficient and may create a gap between decision makers and the SSB.

Regarding the satisfaction of the SSB members with the Sharī'ah secretariat in the bank, most of the interviewees, 96\%, have highlighted that the CBO has put in place excellent requirements in appointing Shari'ah staff and they have agreed about the performance of the Sharī'ah department. The only point the respondents have observed is lack of Omani staff in the bank due to the late launching of Islamic banks in Oman. On the other hand, only one Shari'ah scholar, 4\%, has mentioned that their Sharīah secretariats are not qualified enough in terms of experience and understanding their job.

The interviewees were asked whether the SSB carries out Sharīah review according to the law to assure Sharī'ah compliance in the institution. The study reveals that the respondents unanimously, $100 \%$, have agreed that the $\mathrm{CBO}$ has placed great regulations and mechanisms in terms of allowing the SSB members to ensure Sharī'ah compliance in the bank. Moreover, some respondents have added that this function has been stipulated in the contract from the very beginning. Some interviewees have highlighted that, sometimes, this function is difficult to perform in all transactions of the bank. They have explained that it is hard for the SSB members to move from one branch to the other to ensure Sharī'ah compliance due to lack of incentives as well as time.

The findings indicate that the $\mathrm{CBO}$ has a solid Shari'ah governance framework in place, and it has many features and advantages which make it one of the best frameworks around the world. Most of the interviewees have given many examples of these features and strengths, such as segregation of responsibilities of all the key functions, which is difficult to find in other Sharīah governance frameworks. From the interviews, it is discovered that the SSB communicates effectively with other organs, such as the BOD and executive management. However, this communication needs to be improved in a few Islamic banks in terms of the number of meetings and their effectiveness. Some Sharīah scholars have suggested that at least one member of the SSB should attend the meeting of the BOD regularly to bridge the gap between the BOD and the SSB. Most of the SSB members are satisfied with the Sharī'ah staff in the banks and they have good experience in their job. However, in some Islamic banks, the Sharīah secretariats need to enhance their experience and the quality of their job. It should be proposed by the management of the Islamic banks to be more focused on the qualification and real experience of the Sharī'ah secretariat. The mechanism and strategy put in place in the Islamic banks to ensure Sharī'ah compliance by the SSB is good enough. By this law, the SSB is able to ensure Sharī'ah compliance in the bank. To enhance this mechanism, this study proposes that Islamic banks should send their Sharīah officers regularly to all branches to guarantee compliance with Sharī'ah in all transactions.

\subsection{Analysis of the Problems and Weaknesses of Sharī'ah Governance Framework Q (9-11)}


Three questions were posed to the respondents in this section. The researchers have created these questions in order to investigate the interviewees' opinions on Sharī'ah governance matters, the AAOIFI governance standards and the effect of weak Sharī'ah governance on the operation of Islamic banks in Oman.

With regards to the main issue currently faced in relation to Sharīah governance in Oman, some respondents, $48 \%$, have mentioned that they have not observed any issues in the current Sharī'ah governance framework of Oman. However, some interviewees, $20 \%$, have highlighted some main issues namely, lack of experience, prevention of tawarruq, lack of Islamic finance research, lack of human resources especially among Omanis, inadequate experts in the CBO in Islamic finance, the low position of internal Sharì'ah reviewer and lack of experience of external Sharī'ah auditors. Some respondents, $12 \%$, have explained that many officials of Islamic banks do not have enough knowledge about Islamic finance, and they think the only difference between Islamic banking and conventional banking is just the name. The reason behind this, according to the respondents, is that many staff of Islamic banks come from conventional banks without studying any intensive course in the field of Islamic banking. Moreover, some interviewees, 20\%, have highlighted that external Sharī'ah auditors come from conventional auditing and they do not have enough experience in Islamic finance. Even though the IBRF has stated good requirements for appointing an external Sharī'ah auditor, the problem still occurs. This problem creates conflicts in the operation between internal Sharī'ah auditors in the bank and external Shari'ah auditors. Some respondents have admitted that the CBO lacks experience and very few researches have been conducted on Islamic finance in Oman by the $\mathrm{CBO}$. The $\mathrm{CBO}$ as the regulator of Islamic finance in the country should have experts in the field and embark on research in order to boost the level of the industry in Oman. Many interviewees have mentioned that there is not enough human power to work in the Islamic banks, especially among the Omanis. Although Islamic banks are encouraged by the CBO to appoint Omani staff to enhance their experience in Islamic finance, there is still a lack in the number of Omani staff in all Islamic banks. It is interesting to note that most of the internal
Shari' ah reviewers have highlighted that the position of internal Sharī'ah reviewer as the head of Sharī'ah department is lower than the head of other departments such as internal auditor. This matter may weaken the level of Sharī'ah governance in Islamic banking. An internal Sharīah reviewer has no power to prevent Sharī'ah non-compliance because of his position which has no privilege to force other departments to comply with Sharī'ah as stated by the SSB. Moreover, some of the respondents have shown concerns that the IBRF has stated that the management in consultation with the SSB has the right to dismiss or terminate the appointment of an internal Sharī'ah reviewer. This may lead to abuse of power if the management dismisses the internal Sharīah reviewer without any convincing reason. In order to prevent this, the respondents have suggested that the management should obtain the approval of the CBO before starting the process of dismissing an internal Sharīah reviewer. This may enhance the position of internal Sharī'ah reviewer as one of the key players of the Sharī'ah governance of the bank.

In terms of the AAOIFI governance standards, the interviewees were asked whether they have believed the adoption of the AAOIFI governance standards may resolve issues of Sharī'ah governance. Most of the respondents, $84 \%$, have stated that AAOIFI governance standards are very stringently applied. Moreover, AAOIFI has specialists from different countries which is very helpful to place the Oman Islamic banking on a firm foundation. On the other hand, some respondents, $16 \%$, have believed that AAOIFI governance standards will not resolve the problems of governance in Oman. They have explained further that the Sharīah governance framework of Oman has avoided many disadvantages of many countries around the world; and Oman has its own environment which combines the three madhabs (Ibadi, Sunni and Shi'i). Moreover, AAOIFI itself has declared that Sharī'ah governance of Oman is a good model and example for many countries. Furthermore, AAOIFI has adopted some ideas from Oman in some issues.

With regards to the impact of poor Sharīah governance practice on Islamic banks, majority of respondents, $92 \%$, have mentioned the importance of a solid Sharī'ah governance in the Islamic bank, and the 
adverse effects that poor Sharì'ah governance may have on the operation and Sharī'ah compliance of the Islamic bank. However, two interviewees, $8 \%$, have said that some serious issues occurred because of the weak Sharī'ah governance practiced by their Islamic banks. Moreover, they have mentioned some examples of these practices, such as lack of experience of Shari'ah staff in the bank and lack of experts in the CBO. Furthermore, one Sharī'ah scholar has added another issue where there were undue influences on the SSB in making decisions and fatwa.

With regards to the main challenges of Sharī'ah governance framework in Oman, the respondents have drawn attention to a few matters of concern. The study summarizes these issues into two main sections which are: regulators' issues; and practitioners' issues. The regulators' issues include lack of experience of Shar' 'ah staff in the CBO, lack of research in the field of Islamic banking and finance in Oman, and external Sharī'ah auditor's lack of experience. The practitioners' problems include lack of Omani staff in the bank, lack of human resources and lack of experience on the part of the Sharì'ah staff.

In order to solve these issues, the study suggests that the regulators need to focus more on enhancing the training of the staff of Sharì'ah department in the CBO for improved efficiency. This can be done by sending their staff for training in the more developed countries in Islamic finance such as Malaysia and Bahrain. To improve the research in the field of Islamic banking and finance in Oman, the $\mathrm{CBO}$ is encouraged to create a department of research in the CBO itself. Furthermore, the CBO may issue a journal and organize conferences focusing on Islamic banking in Oman and its challenges to encourage and attract researchers around the world to participate and help the development in this area. With regards to the external Sharī'ah auditor, the regulators are required to review the requirements of appointing external Sharī'ah auditors, which is very crucial. The requirements should include adequate experience in auditing and Sharī'ah (fiqh muamalat).

On practitioners' issues, Islamic banks are required to train their staff properly on Sharī'ah issues because many of them came from conventional banks without having any qualifications or intensive knowledge on Sharī'ah matters. Moreover, Sharī'ah staff have a duty to ensure Sharì'ah compliance in the bank; therefore, they should have more training in the field of Islamic banking and Sharī'ah as well. Islamic banks are also encouraged to appoint more Omani staff as required by the IBRF. Islamic banks in Oman have to reconsider the position of the internal Sharīah reviewer, who is the safeguard of Sharì'ah compliance in the bank. Furthermore, he is representing the SSB in the bank. AAOIFI (GS, 3, 910) states that "the status of internal Sharī'ah reviewer shall not be lower than that of the internal audit department or internal control department". According to Mihajat (2018), for some Islamic banks in Oman, the internal Sharì'ah reviewer cannot impose Sharīah decisions on the respective departments in the case of Sharī'ah non-compliance occurring in the transactions and activities of Islamic banks.

Therefore, Islamic banks in Oman should elevate the position of internal Sharì'ah reviewer in the bank to be at the same level with other departments such as audit department. This will cause other staff to respect his instructions and decisions which are coming from the SSB.

AAOIFI governance standards are set by many experts and scholars around the world. Oman may get benefits from these standards and may solve issues regarding governance. This study proposes that the regulators may get benefits from AAOIFI governance standards in terms of the requirements of the external Sharī'ah auditor and the independence of internal Sharī'ah reviewer. At the same time, Oman has got a great Sharīah governance framework which has obtained advantages from many countries around the world. Therefore, AAOIFI itself may get some advantages from Omani Sharīah governance framework in terms of the requirements and duties of other functions such as Sharì'ah audit and Sharì'ah compliance.

Poor Sharī'ah governance has a major effect on the Islamic banks in general. According to the respondents, some Islamic banks in Oman have some weaknesses in implementing the Sharī'ah governance framework. Therefore, the regulators are required to pay more attention to Islamic banks which are not implementing the Sharī'ah governance framework very well. Some of these weaknesses also relate to the 
appointment of staff of the Sharī'ah department and their experience.

\subsection{Analysis of Main Issues of Sharī'ah Governance Framework}

\subsubsection{Competency $Q(12-15)$}

The respondents were asked four questions in this section. The study has generated these questions in order to examine the competency of the Shari'ah governance framework of Oman. The areas of focus include requirements, training, assessment and qualification of SSBs in Islamic banks in Oman.

In terms of the competency requirements of the $\mathrm{SSB}$, most of the interviewees, $92 \%$, have agreed that the $\mathrm{CBO}$ has set strong requirements for the appointment of the SSB members. Some of the respondents have added that these requirements are crucial for the SSB members as a safeguard of Shari' 'ah compliance in the bank and to perform their responsibilities properly. However, one of the SSB members, $4 \%$, has mentioned that it is good but the CBO must be more flexible with Omani Sharīah scholars due to lack of experience in the field of Islamic banking. Some other respondents have commented that Omani members of the SSB need more experience in Islamic banking and finance to keep up with their colleagues in the board. The Grand Mufti of Oman has commented on a question pertaining to the competency of the SSBs and he responded: "I do not know all the people who are working in the SSBs, but they should know themselves better. If they do not have the competency and ability to bear the responsibilities, they should not accept the position."

In terms of training of the SSB members, $60 \%$ of respondents have admitted that their banks have provided adequate training in different fields, such as economy, finance and Basel III. Basel III is "an internationally agreed set of measures developed by the Basel Committee on Banking Supervision in response to the financial crisis of 2007-09" (Basel III, 2017). Moreover, one of the SSB members commented that Oman is the first country in the world to impose on SSB members to do some courses yearly. On the other hand, some interviewees, $28 \%$, have acknowledged that the courses provided for the SSB members are not enough and that there should be more, especially in the nonSharī'ah aspects. Moreover, the CBO itself should organize some courses yearly for Omani SSB members to improve their skills in different aspects, such as finance and economy. It is interesting to note that some SSB members, $12 \%$, who had more than 20-years' experience in the field of Islamic banking and finance have highlighted that not all SSB members need to be trained because some of them are already experts. Therefore, training should be for the members who do not have enough experience or have less than 10 years in service.

This study finds that majority of the respondents, $84 \%$, have agreed that the SSB members are evaluated by the BOD annually which is stated in the IBRF. Moreover, they have added that this assessment is sent to the $\mathrm{CBO}$ to give an overview of the SSB's performance. On the other hand, $8 \%$ of interviewees have admitted that there is no real assessment for the SSB members' performance and quality. The assessment focuses only on the attendance and absence which is very basic. Due to the busy workload of the BOD, the assessment, many times, was done by the management, who has no right to evaluate the SSB members. On the other hand, some respondents, $8 \%$, have admitted that the SSBs should not be evaluated based on performance because they have experience in their field; they have worked for more than 20 years. It is worth to mention that a member of HSSA revealed that many SSB members have asked about matters which are not within the scope of their job in monitoring the Sharìah compliance in the bank. Therefore, the SSBs should focus more on the needs for improvement of the Sharì'ah compliance mechanism in the bank.

The interviewees have different views on the issue of interdisciplinary members of SSB. Most of the respondents, $60 \%$, have agreed that the SSB should have some members of non-Sharī'ah background to give better understanding on the issue under review. This group of respondents have mentioned one condition which is that these members without any Shari' 'ah background must not have the right to vote in the board. On the other hand, some respondents, $40 \%$, have admitted that SSB should consist of members with Shari'ah background only, and that the board can call 
non-Sharī'ah experts when necessary. They have added that the Islamic banks have different departments in order to give the SSB the whole picture of deliberated issues. Moreover, they have stated that members without voting rights should be called consultants not the SSB members and these consultants may perform their duties whenever necessary.

To sum up, focusing on the issues of competency of the SSB has drawn attention to some matters of concern. The first matter is the competency requirements in Sharīah governance framework of Oman. The findings show that most interviewees have agreed that the IBRF has excellent competency requirements. However, some respondents have proposed that the $\mathrm{CBO}$ should be more flexible in appointing Omani members of the SSB due to their lack of experience in the field of Islamic banking and finance.

The second issue is the amount of training which should be given to the SSB members. The respondents have different views on this issue. Most of the Islamic banks provide adequate training for the SSB members, while some other banks do not even though it is a legal requirement in the IBRF for the SSB members to be trained. Therefore, all Islamic banks are required to provide adequate training for the SSB members to help them enhance their experience. Moreover, the CBO are encouraged to provide, at least, one course annually, especially, for Omani members to improve their knowledge in the field of Islamic banking and finance.

Third is the issue of assessment of the SSB. Most of respondents have stated that there was a basic assessment of the SSB members done by the BOD. However, this assessment in some banks is done by the management which is not in compliance with Sharì'ah governance because the management has a lower level than the SSB. Therefore, the study reveals that Islamic banks are required to be more serious with regards to the authorized body who has the right to assess the SSB members to be safe from any avoidable problems. Moreover, this study proposes that this assessment can be done by the chairman of the SSB because he recognizes the members properly.

Fourth is the issue of interdisciplinary members of the SSB. Even though it is a legal requirement by the IBRF, the respondents have different opinions on this issue. The practice shows that some Islamic banks appoint members of the SSB from Sharīah background only. However, most of the Islamic banks have members from non -Sharī'ah background in their SSB. The reason behind this is that members from non -Shariah background may help in giving a clearer picture of the deliberated issue.

\subsubsection{Independence $Q(16-19)$}

The study identifies four questions pertaining to independence of the SSBs. The first question attempts to find out who has the power to appoint and dismiss the SSB. The second question explores who determines the Sharī'ah board's remuneration. The fourth question investigates the SSB in terms of making pronouncements, while the last question examines the extent of Islamic banks' compliance with the SSB decisions.

With regards to appointment and dismissal of the SSB members, the respondents have two opinions. One group, $40 \%$, have admitted that the shareholders in the AGM should be vested with the power to appoint and dismiss the members of the SSB. The other group, $60 \%$, is of the view that even though the IBRF states that the appointment of the SSB shall be made by shareholders in AGM, this power can be given to the BOD on behalf of the shareholders, as done by some Islamic banks. Some respondents have added that the reason behind this is the tight schedule of shareholders. Delegating the power to the BOD will enhance the effectiveness and smooth running of the system.

On the determination of remuneration of the SSB members, most of the respondents, $60 \%$, have acknowledged that this is a duty of the BOD. Moreover, some interviewees have added that BOD took this responsibility because they know the market rate and they are closer to the daily business of the bank. On the other hand, some interviewees, $40 \%$, have admitted that the shareholders determine the remuneration of the SSB members in the AGM. The interviewees were also asked a question regarding the extent of the impact of remuneration on the independence of the SSB. The respondents have stated that the SSB get remuneration for the services rendered to the bank, which is monitoring the Sharī'ah compliance. They have added that some sensitive professions, such as judiciary, get 
paid by the government although they are required to be independent. Moreover, there is always a system to protect the independence of SSB members to ensure Sharī'ah compliance all the time.

Concerning the independence of the SSB in making pronouncements, most of the respondents, 96\%, have agreed that the SSBs have full independence in terms of making pronouncements. Some of them have added that, sometimes, the SSB rejects some transactions even though the bank wants to execute them. Moreover, a member of the SSB has the right to disagree with opinions of other members in the meeting and his disagreement will be recorded. The CBO is fully supportive, and it gives full rights to the SSB to reject anything that may affect its independence. On the other hand, one SSB member, 4\%, has acknowledged that the SSB has independence theoretically, but, in practice, it has no independence. Sometimes, the BOD intervenes in the work of the SSB indirectly through other parties to approve some transactions, such as, through the financial auditor. Unfortunately, the SSB does not resist such interventions in those cases.

In terms of abidingness of pronouncements made by the SSB on Islamic banks in daily transactions, all the interviewees were unanimous that the decisions and pronouncements made by the SSB are really binding on the Islamic banks. This principle has been mentioned in the IBFR under title 2 (9) "the fatwa and rulings of the SSB shall be binding on the licensees." Moreover, some SSB members have added that the CBO may penalize the Islamic banks or reject a product in case of violation.

Based on the above, the findings of this study denote that most of the Islamic banks in Oman follow the guidelines issued by the $\mathrm{CBO}$, which gives shareholders the right to appoint, dismiss and determine the remuneration of the SSB members. However, a few Islamic banks give the right of appointing, dismissing and determining the remuneration of the SSB members to the BOD. The reasons given for this are that shareholders are too busy, and that the BOD is closer to the banks in daily businesses. It is worth mentioning at this point that the $\mathrm{CBO}$ should consider the opinion of the Islamic banks that practice this method.

Next, the SSB has full independence to make pronouncements regardless of the impact on the Islamic bank's business. Moreover, members of the SSB have the right to disagree with their colleagues in issuing fatwa. Based on the interview, only one Islamic bank puts some pressure on the SSB's independence in making decisions. This action affects the independence of the SSB and constitutes a high risk to the whole Sharì'ah governance of this Islamic bank. Furthermore, the SSB members are required to be more courageous in resisting any pressure put on them by any party. Similarly, the CBO is encouraged to be closer to the SSB members and ask them about the problems they may be facing or affecting their work. All interviewees have agreed that all the pronouncements of the SSB are really binding on Islamic banks in their daily transactions, which indicate the high level of respect given to the SSB by Islamic banks in Oman.

\subsubsection{Disclosure $Q(\mathbf{2 0 - 2 2})$}

The interviewees were asked three questions on issues relating to disclosure. These questions were generated by the study to investigate the disclosure level of the Shari' 'ah governance framework of Oman and relevant issues. The first question examines the access of the SSB to all documents and records in the bank. The second question finds out whether the confidential nature of the job is mentioned in the letter of appointment. The third question finds out whether the SSB gets adequate information disclosed by the bank, which helps them in making informed decisions.

In terms of the access to all documents, majority of interviewees, 92\%, have agreed that the SSB members have full access to all necessary information and documents which they may need at any time as stated by the law in the IBRF. The respondents have emphasized that the SSB has not found anything that prevents it from getting access to any information. However, some members of the SSB, $8 \%$, have mentioned that the SSB has access to only the documents relevant to Sharì'ah. These respondents have mentioned that the SSB views the documents through the Sharīah department only. The SSB members do not review the documents by themselves; there is the tendency that this may cause mistakes because vital decisions should not be made if the SSB does not have the necessary information. Regarding the confidentiality clause in the appointment letter, most of 
the respondents, $88 \%$, have maintained that their Islamic banks stated clearly the issue of confidentiality in their appointment letters. They have added that this issue is very significant in protecting the business of the bank and avoiding the potential conflict of interest in the future. However, two interviewees, $8 \%$, from different banks have acknowledged that the bank did not mention anything on confidentiality in their letters of appointment; while a member of the SSB, $4 \%$, has not remembered exactly what was written in his appointment letter about confidentiality.

Regarding disclosure of adequate information to the SSB by Islamic banks, most of the respondents, $92 \%$, have admitted that the SSB obtains necessary and important information which help it in making fatwas or decisions. Furthermore, the SSB has the right to ask about any documents it wants at any time. One of the interviewees has added that Oman is one of the few countries that disclose many things about the SSB, such as their remuneration, position and background, which many countries do not disclose. In contrast, two interviewees, $8 \%$, from different banks have acknowledged that, sometimes, the SSB does not get adequate information about issues under deliberation, especially pertaining to non-Sharī'ah aspects. This information is very important in getting comprehensive ideas about the issues discussed. Therefore, the SSB is required to ask about any information felt to be necessary to get a full picture of any transaction before a verdict is made on it.

Based on the findings above, this study reveals that the IBRF has set standard rules on confidentiality by providing clear guidelines. This will assist the SSB members to perform their job efficiently. Moreover, most of the interviewees were satisfied that their assignment was made confidential by their Islamic banks; this will enhance their performance. On the other hand, some of the SSB members are required to be more courageous on any matters that may affect confidentiality. The SSB members are encouraged to review any necessary documents by themselves and not to rely on the Sharīah department only. Moreover, the SSB members should request for any missing documents that may help in making their fatwa or decision. In this respect, the IBRF has given the SSB the right to inform the $\mathrm{CBO}$ of any issue that may affect their confidentiality and performance of their duties. The managements of some Islamic banks are required to be more cooperative and not to hide any important documents that may help the SSB to make their final decision. Moreover, the management should facilitate the process for the SSB and Sharī'ah Department as well, when they request for any documents or information relevant to any issues under deliberation. Cooperation of the management will enhance the task of the SSB as a safeguard of Sharī'ah compliance in the banks. As a result, it would boost the whole mechanism of Sharī'ah governance in the banks.

\subsection{Analysis of Recommendations and Suggestions Q (23-24)}

With respect to issues observed by the interviewees, some of the respondents have stated that there is no serious issue and Sharī'ah governance framework of Oman is still in its initial stage. The regulators and practitioners are doing well, but there are rooms for improvement. However, most of the interviewees $(60 \%)$ have acknowledged that there are weaknesses which include lack of human capital, especially, in the Sharī'ah Department, lack of experience of the external Sharī'ah auditor in terms of Sharī'ah knowledge, position of internal Sharīah reviewer, the independence of the SSB and the interpretation of the HSSA decisions by non-specialists in the Islamic banks.

The main problems of Sharīah governance given by the respondents can be summarized into two types which are lack of experience and problems relating to practices. To solve these problems, all Islamic banks and regulators are required to sit together and find practical solutions to the previous issues. At the same time, the SSB should discuss its concerns about its work with the BOD of the bank and the HSSA. A question was posted to the $\mathrm{CBO}$ pertaining to its plan to asses and evaluate the Sharīah governance framework. The CBO replied, "we do not feel an urgent need to evaluate the Sharì'ah governance framework within the IBRF; hence there is no plan to refine, redefine, evaluate, or amend it, in the near future." Based on the findings, the researchers think that the regulators should evaluate the Sharī'ah governance framework within the IBRF. This evaluation may help 
to find problems and weaknesses faced by key players of Sharī'ah governance and try to solve them.

Regarding the suggestions on how to improve the Sharì'ah governance framework of Oman in relation to disclosure, competency and independence, the respondents have proposed some suggestions which can be summarized as follows:

1- Regular meetings and direct communication must be initiated among the SSB members themselves, and between the SSB and the HSSA;

2- Intensive training should be organized by the CBO for the Omani members of the SSB in the field of Islamic banking and finance;

3- Elevating the position of the internal Sharī'ah reviewer in the Islamic banks;

4- The HSSA should consult the SSB before making any pronouncement pertaining to the SSB matters;

5- Decisions made by the HSSA must not be compulsorily binding on the SSB;

6- Creating an internal ethical governance in all Islamic banks to enhance Islamic values in the behaviours of employees;

7- Reducing the number of Islamic windows offering Islamic finance in Oman;

8- Direct communication between the internal Shari' 'ah reviewer and the HSSA;

9- Spreading the culture of Islamic banks among all shareholders;

10- Appointing an external Sharī'ah auditor based on specialization and experience in the field of Islamic banking and finance;

11- Review of the Sharī'ah governance framework must be done by the CBO.

Observably, the interviewees have provided valuable suggestions and recommendations on how to improve the Shari' ah governance framework of Oman. It can be seen that some suggestions are pertaining to the regulators and the practitioners in the Islamic banking industry. Even though some of these suggestions are not relevant to Sharī'ah governance directly, they may benefit the respective parties to improve the whole industry of Islamic banking and finance in Oman.

\section{Conclusion}

Based on semi-structured interviews, the findings of this study have demonstrated that there are some important points pertaining to the Sharì'ah governance framework of Oman, which must be highlighted. The regulators have put in place an excellent Sharīah governance framework and it is considered to be one of the best frameworks in the Islamic banking industry. Furthermore, the HSSA plays a great role in organizing and harmonizing the Sharī'ah scholars' views. However, the HSSA as the regulatory body is required to give more room for independence for the Sharì'ah scholars. The study reveals that the CBO has set great rules on confidentiality, independence and disclosure by providing clear guidelines.

The Sharì'ah governance framework of Oman needs some improvement in several issues. These important issues need attention by regulators and practitioners as well. One of these issues is that the industry of Islamic banking and finance started in Oman in the last few years; therefore, there is a need to improve the knowledge of Islamic banking and finance among the staff of the banks and the society as well. This can be done by providing intensive training and courses for the staff and awareness programmes for the general public.

Moreover, the study has found some weaknesses in the Sharī'ah governance framework, such as lack of experience of Sharīah staff in the CBO, lack of research in the field of Islamic banking and finance in Oman and lack of experience of the external Sharī'ah auditor in Sharī'ah knowledge. The Sharī'ah reviewer represents the eyes of the SSB and he is the head of the Shari' 'ah department in the bank. Therefore, he should enjoy a strong position to execute his job effectively.

\section{References}

AAOIFI (2015). Governance Standard for IFIs, No. 1-7. Bahrain: AAOIFI.

Abdul Aziz, A. (2012). Sharīah Governance Challenges Ahead. MPRA Paper No. 47772, posted 24. June 2013 04:09 UTC

Al-Maward̄̄, A. (1989). Al-Ahkām al-Sultāniyya Wal-Wilāyāt al-Dīniyya, ed. Ahmad Al-Baghdadi. Kuwait: Dar Ibn Qutaibah, 315. Sharī'ah Governance Book, 60. 
Bakar, M.D. (2002). The Sariah Supervisory Board and Issues of Shari'ah Rulings and Their Harmonization in Islamic Banking and Finance. In Archer, S. and Riffat, A. A. K. (Eds), Islamic Finance Innovation and Growth. Bahrain: Euromoney Books and AAOIFI.

Basel III. (2017). International Regulatory Framework for Banks. The Bank for International Settlements. www.bis.org/bcbs/basel3.htm.

Belder, T., Sapte, D., \& LLP. (2008). Sharia Supervisory Boards and Sharia Compliance. In Millar, $R \&$ Anwar, H. Hand book Islamic Finance: A Guide for International Business and Investment GMB Publishing Ltd, (185- 192).

Blee, K.M., \& Taylor, V. (2002). Semi-Structured Interviewing in Social Movement Research. In Klandersmans, B. and Staggenborg, S. (Eds.), Methods of Social Movement Research, 92-117. Minneapolis: University of Minnesota Press.

Bryman, A. (2001). Social Research Methods. Oxford: Oxford University Press.

CBO. (2012). Islamic Banking Regulatory Framework. Central Bank of Oman Muscat.https://cbo.gov.om/Pages/IslamicBankingRe gulatoryFramework.aspx

Farook, S., \& Farroq, M. (2011). Sharīah Governance for Islamic Finance: Challenges and Pragmatic Solutions. at: http://ssrn.com/abstract $=1813483$

Garas, S., \& Pierce, C. (2010). Sharìah Supervision of Islamic Financial Institutions. Journal of Financial Regulation and Compliance, 18(4), 386-407.

Ginena, K., \& Hamid, A. (2015). Foundation of Sharì'ah governance of Islamic banks. Southern Gate, Chichester, West Sussex, PO19 8SQ, United Kingdom.

Grais, W., \& Pellegrini, M. (2006). Corporate Governance and Sharīah Compliance in Institutions Offering Islamic Financial Services. World Bank Policy Research Working Paper No. 4054. Available at: http://wwwwds.

worldbank.org/external/default/WDSContentServer/I W3P/IB/2006/11/08/000016406_20061108095535/R endered/PDF/wps4054.pdf. Access Date: 10th June 2017.

Gruening, H., \& Iqbal, Z. (2008). Risk Analysis for Islamic Banks. The World Bank, Washington D.C.

Hamza, H. (2013) "Sharì'ah Governance in Islamic Banks: Effectiveness and Supervision Model". International Journal of Islamic and Middle Eastern Finance and Management, $\quad 6(3), \quad$ 226-237. https://doi.org/10.1108/IMEFM-02-2013-0021

Hasan, Z. (2011). A Survey of Sharì'ah Governance Practices in Malaysia, GCC Countries and the UK: Critical Appraisal. International Journal of Islamic and Middle Eastern Finance and Management, 4(1). 3051.

Ibn Manzūr, M. (1999). Lisān Al- 'Arab, (3rd ed.). Beirut: Dar Ihyā Al-turāth Al- 'Arabi, 3, 164.
ISRA. (2016). Islamic Financial System: Principles and Operations. Kuala Lumpur: International Sharì'ah Research Academy for Islamic Finance.

Lahsasna, A., \& Saba, I. (2014). Shari'ah Governance in the Islamic Financial Institution: Issues and Challenges. $5^{\text {th }}$ International Conference on Business and Economic Research (5 ${ }^{\text {th }}$ ICBER 2014) Proceeding, $24-25$.

Mihajat, I.S. (2018). Shari'ah Governance Framework in Islamic Banking in Oman: Issues and Challenges. Journal of Islamic Banking and Finance, 35(3), 7383.

Rammal, H.G. (2006). The Importance of Shari'ah Supervision in Islamic Financial Institutions. Corporate Ownership and Control, 3(3), 204-208.

Wilson, R. (2009). Sharīah Governance for Islamic Financial Institutions. ISRA International Journal of Islamic Finance, 1(1), 59-76.

\section{Appendix}

\section{SEMI-STRUCTURED INTERVIEW QUESTIONS}

An interview about Sharī ah governance framework of Islamic banking in Oman.

\section{\# Process}

\section{(A) View (Practice)}

1) What is your view on the Shari'ah governance framework of Oman?

2) What is the Sharī $a h$ process you have to ensure the Sharī'ah compliance in the Islamic bank?

3) What are the roles of the Sharī'ah board?

4) Do you prefer centralized SSB in the central bank or no?

\section{(B) Key functions (Features and weaknesses)}

5) In your opinion, what are the main features and strengths of Sharì 'ah governance framework of Oman?

6) Do you think that the SSB communicates effectively with other organs of governance, including the BOD, management and auditors?

7) What is your view about the Sharī $a h$ Department (Sharī'ah Secretariat) in the bank you work with? Are you satisfied?

8) Does the bank by-laws allow you to carry out a Sharī $a h$ review to ensure

that the bank's operation is in accordance with Sharī ah?

\section{(C) General Issues (Problems)}

9) What is the main issue you currently face in relation to Sharī'ah

governance in Oman? 
10) Do you think that the adoption of the AAOIFI governance standards may

resolve issues of Sharī'ah governance?

11) Are you aware of any failure or serious impact on the Islamic banks directly

or indirectly attributable to the poor Sharī'ah governance practices?

\section{\# Main issues}

\section{(A) Competency}

12) What is your view on the competency requirements in Sharī 'ah governance framework of Oman?

13) Does the bank organize adequate training for the SSB?

14) Is there any assessment or evaluation of the SSB?

15) What is your view on interdisciplinary members of the SSB?

\section{(B) Independence}

16) Who has the power to appoint and dismiss the SSB?

17) Who determines the Sharīah board's remuneration?

18) Do you think that the HSSA will affect the independence of the SSBs?

19) Do you think the SSB has full independence in terms of making pronouncement?

\section{(C) Disclosure}

20) Do you think that the Shari ' $a h$ board has the access to all documents, information,

records, etc.?

21) Is the provision of confidentiality clearly mentioned in the terms of

reference in the letter of appointment?

22) Do you think that adequate information are disclosed to the SSB by the Islamic banks in making an informed decision?

\section{\# Recommendations}

23) Have you observed any other issues pertaining to Sharì 'ah governance framework of Oman?

24) Do you have any suggestions on how to improve the Sharī 'ah governance framework of Oman in terms of disclosure, competency and independence? 